\title{
Compressed matrix dual-component vaginal drug delivery system containing metoclopramide hydrochloride
}

GEETA M. PATEL ${ }^{1, *}$

MADHABHAI M. PATEL ${ }^{2}$

${ }^{1}$ Department of Pharmaceutics and Pharmaceutical Technology,

S. K. Patel College of Pharmaceutical

Education and Research

Ganpat University

Kherva-382711, Gujarat, India

${ }^{2}$ Kalol Institute of Pharmacy

Kalol, Gujarat, India

Accepted July 22, 2009
The purpose of the present investigation was to produce a quick/slow biphasic delivery system for metoclopramide hydrochloride using the superdisintegrant Ac-di-sol for the fast release layer and hydroxypropyl methylcellulose K100M and Ucarflock 302 to modulate the release of the drug. A dual component tablet made up of a sustained release and an immediate release layer was prepared by direct compression. A $3^{2}$ full factorial design was applied to systematically optimize the drug release profile of the sustained release layer. The results of the full factorial design indicate that a small amount of HPMC K100M and a large amount of Ucarflock 302 favor sustained release of the metoclopramide hydrochloride vaginal dual component system. The ex vivo residence time reveals that the formulation was retained for more than $10 \mathrm{~h}$. The formulation gave an initial burst effect to provide the loading dose of the drug followed by sustained release for $12 \mathrm{~h}$, thus solving the problem of repeated administration, especially in pregnancy.

Keywords: dual component system, vaginal drug delivery, metoclopramide, mucoadhesion, factorial design, quick/ slow release

The vagina, as a drug delivery site, offers certain unique features that can be exploited in order to achieve desirable therapeutic effects. By contrast, scientific knowledge of the possibilities of drug delivery via the vagina is limited. The currently available vaginal dosage forms have limitations, such as leakage, messiness and low residence time, which contribute to poor subject or patient compliance (1).

In general, conventional controlled dosage forms delay the release of therapeutic systemic levels and do not provide a rapid onset of action. To modify the release of the drug from these systems, the surface area exposed to a fluid can be restricted by the addition of barrier layers to one or both sides of the tablets (2-4). However, most multilayer sys-

* Correspondence; e-mail: geekhappy2002@yahoo.co.in 
tems attempt to achieve a constant release rate from a tablet rather than biphasic release of the drug. When a single constant rate of drug release does not entirely satisfy the therapeutic objective, a quick/slow delivery system may be an interesting alternative. This biphasic release system can be achieved by the application of an immediate release layer to the conventional layered matrix tablet (5). Biphasic delivery systems are designed to release a drug at two different rates or in two different periods of time; they are either quick/slow or slow/quick. A quick/slow release system provides an initial burst of drug release followed by a constant rate (ideally) of release over a defined period of time. This type of system is used primarily when maximum relief needs to be achieved quickly, and it is followed by a sustained release phase to avoid repeated administration.

The aim of the present work was to design a mucoadhesive biphasic delivery system of metoclopramide hydrochloride using mucoadhesive hydrophilic polymers. Metoclopramide hydrochloride is a potent antiemetic, effective in the treatment of nausea and vomiting associated with cancer therapy, pregnancy, and migraine (6). Renewed interest was added to this drug since it demonstrated, in addition to its antiemetic properties, in vitro and in vivo radio and chemosensitizing properties (7-9). However, the oral bioavailability of metoclopramide hydrochloride is highly variable, showing values between 32 and $98 \%$ due to extensive pre-systemic metabolism (10). Oral forms of metoclopramide hydrochloride often get vomited out before systemic absorption, particularly in case of 2-3 month pregnancy, compelling parenteral or rectal administration where both methods result in low patient compliance. In this regard, intravaginal delivery seems to be an attractive alternative.

\section{EXPERIMENTAL}

\section{Materials}

Metoclopramide hydrochloride was obtained as a gift sample from Maan Pharmaceutical Private Limited, India. Ac-di-sol (crosscarmellose sodium) was kindly provided by the Zydus Research Centre, India. Sodium starch glycolate was purchased from S. D Fine Chemicals, India. Hydroxypropyl methylcellulose K100M (HPMC K100M) and Ucarflock 302, were kindly provided by The Dow Chemical Company, USA. The other ingredients were of laboratory grade.

\section{FTIR spectroscopy}

The drug, polymer and other formulation ingredients were characterized by IR spectroscopy using a FTIR $8400 S$ (Shimadzu, Japan). The spectra were taken in KBr discs in the range of $4000-500 \mathrm{~cm}^{-1}$.

\section{Calculation of total dose and immediate part released (IPR)}

The total dose of metoclopramide hydrochloride was calculated by the following equation using available pharmacokinetics data (11): 
G. M. Patel and M. M. Patel: Compressed matrix dual-component vaginal drug delivery system containing metoclopramide hydrochloride, Acta Pharm. 59 (2009) 273-288.

$$
\begin{gathered}
D R=C \text { ss } \times C l_{\mathrm{T}} \\
F X_{0} / \lambda=C \text { ss } \times C l_{\mathrm{T}}
\end{gathered}
$$

where $X_{0}$ is oral dose, $\lambda$ is dosing interval, $F$ is fractional bioavailability, $D R$ is the dosing rate, Css is the steady state plasma concentration and $\mathrm{Cl}_{\mathrm{T}}$ is total renal clearance. From the above equation, Css for the metoclopramide hydrochloride is $3.36 \mu \mathrm{g} \mathrm{mL}-1$.

$$
I P R=(C s s \times V d) / F=15 \mathrm{mg}
$$

Dose $=I P R\left\{1+\left(0.693 \times t / t_{1 / 2}\right)\right\}=33 \mathrm{mg} \sim 30 \mathrm{mg}$

where $t$ is time up to which controlled release is required and $t_{1 / 2}$ is the drug half-life. Hence, the formulation should release $15 \mathrm{mg}$ (50\%) of the drug within 30 minutes and $1.34 \mathrm{mg}(4.5 \%)$ per hour up to $12 \mathrm{~h}$ thereafter.

\section{Preliminary trials of immediate release and sustained release layers}

In the composition of the immediate drug release layer, two superdisintegrants, Ac-di-sol and sodium starch glycolate, of different concentrations were tested. Required quantity of the drug, either superdisintegrant and microcrystalline cellulose were mixed thoroughly.

The sustained release layer was composed of the maintenance dose (15 $\mathrm{mg}$ ) of the drug and different hydrophilic polymers such as HPMC K100M and Ucarflock 302 along with microcrystalline cellulose as a filler. All the ingredients were mixed thoroughly. The quantity of powder for the sustained release layer was compressed lightly using a single-punch tablet compression machine (Cadmach Machinery Co. Pvt. Ltd., India) equipped with 13-mm round, flat and plain punches. Over this compressed layer, the required quantity of the fast release layer was placed and compressed to obtain hardness in the range of $5-6 \mathrm{~kg} \mathrm{~cm}^{-2}$ to form a bilayer matrix tablet. Formulation of preliminary trial batches of the immediate release layer and sustained release layer is shown in Tables I and II, respectively.

Table I. Preliminary trial formulations of the immediate release layer

\begin{tabular}{lrrrcc}
\hline Ingredient & G1 & G2 & G3 & G4 & G5 \\
\hline Metoclopramide $\cdot$ HCl & 15 & 15 & 15 & 15 & 15 \\
Ac-di-sol & 5 & 6 & 7 & - & - \\
SSG & - & - & - & 2.5 & 3.5 \\
MCC & 75 & 74 & 73 & 77.5 & 76.5 \\
Magnesium stearate & 2 & 2 & 2 & 2 & 2 \\
Talc & 3 & 3 & 3 & 3 & 3 \\
\hline
\end{tabular}

SSG - sodium stearate glycolate

MCC - microcrystalline cellulose 
G. M. Patel and M. M. Patel: Compressed matrix dual-component vaginal drug delivery system containing metoclopramide hydrochloride, Acta Pharm. 59 (2009) 273-288.

Table II. Preliminary trial formulations of the sustained release layer

\begin{tabular}{lrrrrr}
\hline Ingredients & P1 & P2 & P3 & P4 & P5 \\
\hline Metoclopramide $\cdot \mathrm{HCl}$ & 15 & 15 & 15 & 15 & 15 \\
HPMC K100M & 150 & 50 & 75 & 75 & 100 \\
Ucarflock 302 & 50 & 100 & 75 & 100 & 100 \\
MCC & 275 & 260 & 235 & 260 & 235 \\
\hline
\end{tabular}

HPMC - hydroxypropyl methylcellulose MCC - microcrystalline cellulose

Table III. Composition of factorial design batches

\begin{tabular}{ccccc}
\hline Batch code & \multicolumn{2}{c}{ Coded level } & \multicolumn{2}{c}{ Actual value } \\
\hline F1 & $\mathrm{X}_{1}$ & $\mathrm{X}_{2}$ & $\mathrm{X}_{1}(\mathrm{mg})$ & $\mathrm{X}_{2}(\mathrm{mg})$ \\
F2 & -1 & -1 & 50 & 50 \\
F3 & -1 & 0 & 50 & 75 \\
F4 & -1 & 1 & 50 & 100 \\
F5 & 0 & -1 & 75 & 50 \\
F6 & 0 & 0 & 75 & 75 \\
F7 & 0 & 1 & 75 & 100 \\
F8 & 1 & -1 & 100 & 50 \\
F9 & 1 & 0 & 100 & 75 \\
Check point & 1 & 1 & 100 & 100 \\
\hline
\end{tabular}

$\mathrm{X}_{1}$ - amount of HPMC K100M

$\mathrm{X}_{2}$ - amount of Ucarflock 302

\section{Optimization of sustained release layer by $3^{2}$ full factorial design}

A $3^{2}$ randomized full factorial design was used in the present study. Two factors were evaluated, each at three levels, and experimental trials were carried out in all nine possible combinations. The factors were selected based on a preliminary study. Contents of HPMC K100M $\left(X_{1}\right)$ and Ucarflock $302\left(X_{2}\right)$ were selected as independent variables. The time required for $50 \%$ drug release $\left(t_{50}\right), 80 \%$ drug release $\left(t_{80}\right)$ and $Q_{2}$ (drug release after $2 \mathrm{~h}$ ) were selected as dependent variables. Dependent variables were selected based on the drug release profile of preliminary trial batches and pharmacokinetic data of the drug. The formulation of factorial design batches is shown in Table III. All batches contain $15 \mathrm{mg}$ metoclopramide hydrochloride, $2 \%$ talc, $1 \%$ magnesium stearate and $q$. $s$. microcrystalline cellulose.

\section{Preparation and characterization of dual component vaginal tablets}

For preparation of the quick/slow (dual component) delivery system, the die of the tablet machine was filled manually with a weighed amount of the sustained release component. The sustained release component was then compressed and the fast release 
G. M. Patel and M. M. Patel: Compressed matrix dual-component vaginal drug delivery system containing metoclopramide hydrochloride, Acta Pharm. 59 (2009) 273-288.

Table IV. Formulation of the dual component delivery systems

\begin{tabular}{lc}
\hline Ingredient & Mass of component $(\mathrm{mg})$ \\
\hline Fast release component & \\
Metoclopramide $\cdot \mathrm{HCl}$ & 5 \\
Ac-di-sol & 77 \\
MCC & 2 \\
Magnesium stearate & 3 \\
Talc & \\
Prolonged release component & 15 \\
Metoclopramide $\cdot \mathrm{HCl}$ & 75 \\
HPMC K100M & 100 \\
Ucarflock 302 & 210 \\
MCC
\end{tabular}

HPMC - hydroxypropyl methylcellulose

MCC - microcrystalline cellulose

powder was added to the precompressed sustained release component. The formulations differed in type and concentration of the polymer (HPMC K100M and Ucarflock 302) used to prepare the biphasic vaginal drug delivery. The dual component compressed tablet systems were prepared by direct compression, with flat-tip punches and 13-mm diameter dies using a single punch tablet machine (Cadmach Co. Machinery Pvt. Ltd., India). Formulation of the dual component system is shown in Table IV.

Physical tests for bilayer tablets. - Standard physical tests were performed for bilayer matrix tablets and average values were calculated (12). Mass variation was determined by weighing 20 tablets individually. Resistance to crushing was determined by taking 6 tablets from each formulation using a Pfizer hardness tester (Electrolab Pvt. Ltd., India). Thickness was determined by vernier calipers. Friability was determined by weighing 10 tablets after dusting and placing them in a Roche friabilator (Campbell Electronics, Mumbai, India).

Drug content uniformity. - Ten tablets were finely powdered and an amount equivalent to $30 \mathrm{mg}$ of metoclopramide hydrochloride was accurately weighed and transferred to a $100-\mathrm{mL}$ volumetric flask; $70 \mathrm{~mL}$ of phosphate buffer $\mathrm{pH} 4.5$ was then added. The flask was shaken for $10 \mathrm{~min}$. Finally, the volume was made up to the mark with phosphate buffer $\mathrm{pH} 4.5$ (13). The mixture was then filtered and $1 \mathrm{~mL}$ of the filtrate was suitably diluted with phosphate buffer $\mathrm{pH} 4.5$ to obtain a solution containing about $30 \mu \mathrm{g} \mathrm{mL}-1$ of metoclopramide hydrochloride and analyzed for metoclopramide hydrochloride content at $272 \mathrm{~nm}$ using a Systronic 2201 double beam UV/Visible spectrophotometer (Shimadzu 1700 UV-Visible Spectrophotometer, Japan) and phosphate buffer pH 4.5 as blank.

\section{In vitro dissolution studies}

The release rate of metoclopramide hydrochloride from the sustained release layer was determined using a USP 24 dissolution testing paddle apparatus (14). The dissolu- 
G. M. Patel and M. M. Patel: Compressed matrix dual-component vaginal drug delivery system containing metoclopramide hydrochloride, Acta Pharm. 59 (2009) 273-288.

tion test was performed using $900 \mathrm{~mL}$ of phosphate buffer $\mathrm{pH} 4.5$, at $37 \pm 0.5^{\circ} \mathrm{C}$ at $50 \mathrm{rpm}$. A sample $(10 \mathrm{~mL})$ of the solution was withdrawn from the dissolution apparatus hourly for 12 hours, and the samples were replaced with fresh dissolution medium. The samples were filtered through a $0.45-\mu \mathrm{m}$ membrane filter and diluted to a suitable concentration with phosphate buffer $\mathrm{pH}$ 4.5. Absorbance of these solutions was measured at $272 \mathrm{~nm}$. Cumulative percentage of drug release was calculated using the equation obtained from a standard curve.

\section{Dissolution profile}

The similarity factor $\left(f_{2}\right)$ given by SUPAC guidelines (15) for modified release dosage forms was used as a basis for comparing dissolution profiles. Dissolution profiles are considered to be similar when $f_{2}$ is between 50 to 100 . This similarity factor is calculated by the following formula (16):

$$
f_{2}=50 \times \log \left\{\left[1+(1 / n) \sum_{t=1}^{\mathrm{n}}\left|R_{t}-T_{\mathrm{t}}\right|^{2}\right]^{-0.5} \times 100\right\}
$$

where $n$ is the number of experimental points in the in vitro dissolution assay and $R_{\mathrm{t}}$ and $T_{\mathrm{t}}$ are the mean percentage of dissolved drug from the reference and test formulations.

\section{Kinetic analysis of drug release data}

The drug release data was also fitted to the Korsmeyer equation to describe the drug release from polymeric systems $(17,18)$.

$$
\log \left(M_{t} / M_{\infty}\right)=\log k+n \log t
$$

where $M_{\mathrm{t}}$ is the amount of drug released at time $t, M_{\infty}$ is the amount of drug released after infinite time, $\mathrm{k}$ is a release rate constant incorporating structural and geometric characterstics of the tablet and $n$ is the diffusional exponent indicative of the mechanism of drug release. The $n$ value of 1 corresponds to zero-order release kinetics, $0.5<n<1$ means a non-Fickian release model and $n=0.5$ indicates Fickian diffusion (Higuchi model).

\section{Residence time and aging}

The ex vivo residence time was determined using a locally modified USP paddle apparatus (dissolution test apparatus type I) (14). The dissolution medium was composed of $500 \mathrm{~mL}$ phosphate buffer $\mathrm{pH} 4.5$ maintained at $37 \pm 0.5^{\circ} \mathrm{C}$. A segment of rabbit intestinal mucosa, $3 \mathrm{~cm}$ long, was glued to the surface of a glass slab, vertically attached to the paddle. The mucoadhesive tablet was hydrated from one surface using 1 to 2 drops of phosphate buffer and then the hydrated surface was brought into contact with the mucosal membrane. The glass slide was vertically fixed to the paddle and allowed rotation at $100 \mathrm{rpm}$. The time required for complete detachment of the tablet from the mucosal surface was recorded (mean of triplicate determinations) (19). The study was approved by 
G. M. Patel and M. M. Patel: Compressed matrix dual-component vaginal drug delivery system containing metoclopramide hydrochloride, Acta Pharm. 59 (2009) 273-288.

the Shree S. K. Patel College of Pharmaceutical Education and Research, Institutional Animal Ethics Committee.

For the short term stability study, optimized medicated tablets were stored in glass vials maintained at $40{ }^{\circ} \mathrm{C}, 75 \% \mathrm{RH}$, for 6 months. The effect of storing was bimonthly investigated for physical properties, bioadhesive characteristics and the drug release behavior.

\section{RESULTS AND DISCUSSION}

Fig. 1 demonstrates the FTIR spectra of metoclopramide hydrochloride, HPMC K100M, Ucarflock 302, microcrystalline cellulose and Ac-di-sol. The FTIR spectrum of metoclopramide hydrochloride showed many characteristic peaks of NH-bending, OH-bending $\left(3199.05,3301.28,3410.26\right.$ and $\left.3472.95 \mathrm{~cm}^{-1}\right), \mathrm{C}-\mathrm{H}$ bending $\left(3030.27 \mathrm{~cm}^{-1}\right)$, four characterestic peaks for N-H stretching $\left(2096.69,2491.15,2676.28\right.$ and $\left.2706.22 \mathrm{~cm}^{-1}\right), \mathrm{C}=\mathrm{O}$ stretching $\left(1598.08 \mathrm{~cm}^{-1}\right), \mathrm{CONH}$ stretching (amide) $\left(1538.28 \mathrm{~cm}^{-1}\right)$, asymmetric C-O-C bending $\left(1271.13 \mathrm{~cm}^{-1}\right), \mathrm{C}-\mathrm{Cl}$ aromatic stretching $\left(679.93 \mathrm{~cm}^{-1}\right)$. The same characteristic peaks were observed for the drug-excipient mixture, indicating that no chemical reaction or interaction between the drug and excipients took place.

Prepared dual component tablets were evaluated in terms of various physical parameters and in vitro dissolution profiles. The average mass of tablets was $1000.0 \pm 1.5$ $\mathrm{mg}(n=20)$. The drug content in the dual component tablets was $97.7 \pm 1.1 \%$, their thickness was $3.4 \pm 0.1 \mathrm{~mm}$, and their resistance to crushing was $5.4 \pm 0.01 \mathrm{~kg} \mathrm{~cm}^{-2}$. Conventional compressed tablets that lose less than $1 \%$ of weight are generally considered acceptable. In the present study, the friability was $0.9 \pm 0.03 \%$. Values of the resistance to

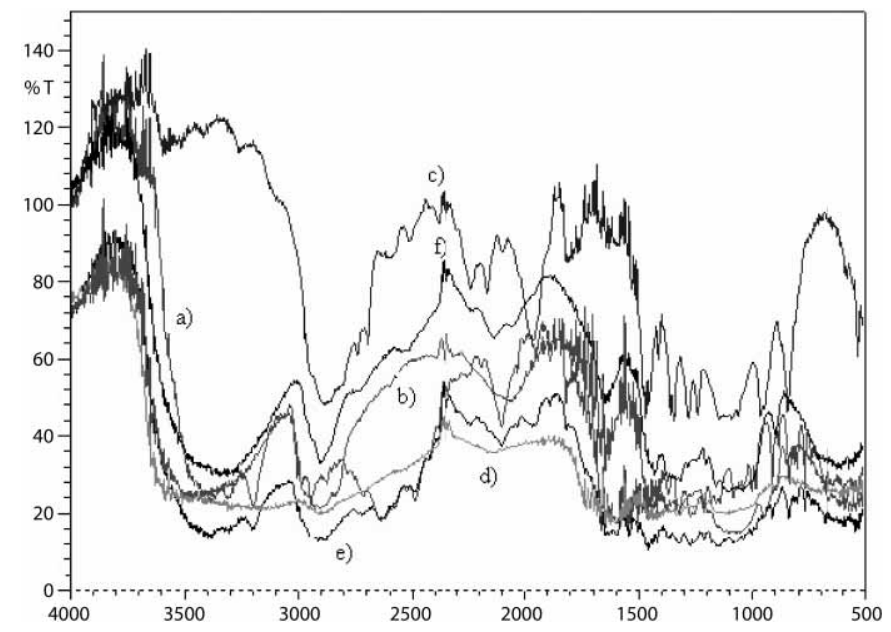

Fig. 1. FTIR spectra of: a) metoclopramide hydrochloride, b) HPMC K100M, c) Ucarflock 302, d) Ac-di-sol, e) microcrystalline cellulose and f) mixture. 
G. M. Patel and M. M. Patel: Compressed matrix dual-component vaginal drug delivery system containing metoclopramide hydrochloride, Acta Pharm. 59 (2009) 273-288.

crushing and percent friability indicate good handling properties of the prepared bilayer tablets. The dissolution data revealed that the formulation containing a larger amount of HPMC K100M released 87 to $89 \%$ of the drug within $12 \mathrm{~h}$ whereas the formulation contaning a larger amount of Ucarflock 302 released 99 to $100 \%$ of the drug within $12 \mathrm{~h}$. Thus, it was directly predicted from the drug release profile that the concentration of HPMC K100M had a significant effect on the drug release rate. The concentration of polymer was further optimized using a $3^{2}$ randomized full factorial design.

The drug release profile of factorial batches (F1 to F9) is shown in Fig. 2. It was found that as the content of HPMC K100M increased, the percentage of drug released decreased. This might be due to higher swellability of HPMC K100M matrices from the surface gel layer, so lower penetration of dissolution medium inside the swelled matrices leads to low availability of fresh dissolution medium inside the matrix and to decreased diffusion of the drug out of matrices.

A $3^{2}$ full factorial design was constructed to study the effect of the amount of HPMC $\mathrm{K} 100 \mathrm{M}\left(\mathrm{X}_{1}\right)$ and the amount of Ucarflock $302\left(\mathrm{X}_{2}\right)$ on drug release from the dual component tablets. A statistical model incorporating interactive and polynomial terms was utilized to evaluate the response:

$$
Y=b_{0}+b_{1} X_{1}+b_{2} X_{2}+b_{12} X_{1} X_{2}+b_{11} X_{1}^{2}+b_{22} X_{2}^{2}
$$

where $\mathrm{Y}$ is the dependent variable, $\mathrm{b}_{0}$ is the arithmetic mean response of nine runs and $b_{1}$ is the estimated coefficient for factor $X_{1}$. The main effects $\left(X_{1}\right.$ and $\left.X_{2}\right)$ represent the average results of changing one factor at a time from its low to high value. The interaction terms $\left(X_{1} X_{2}\right)$ show how the response changes when 2 factors are changed simultaneously. The polynomial terms $\left(\mathrm{X}_{1}^{2}\right.$ and $\left.\mathrm{X}_{2}{ }^{2}\right)$ are included to investigate nonlinearity. The $t_{50}$, $t_{80}$, and $Q_{2}$ values for nine batches (F1 to F9) showed wide variations; results are shown in Table V. The data clearly indicate that the values of $t_{50}, t_{80}$, and $Q_{2}$ are strongly de-

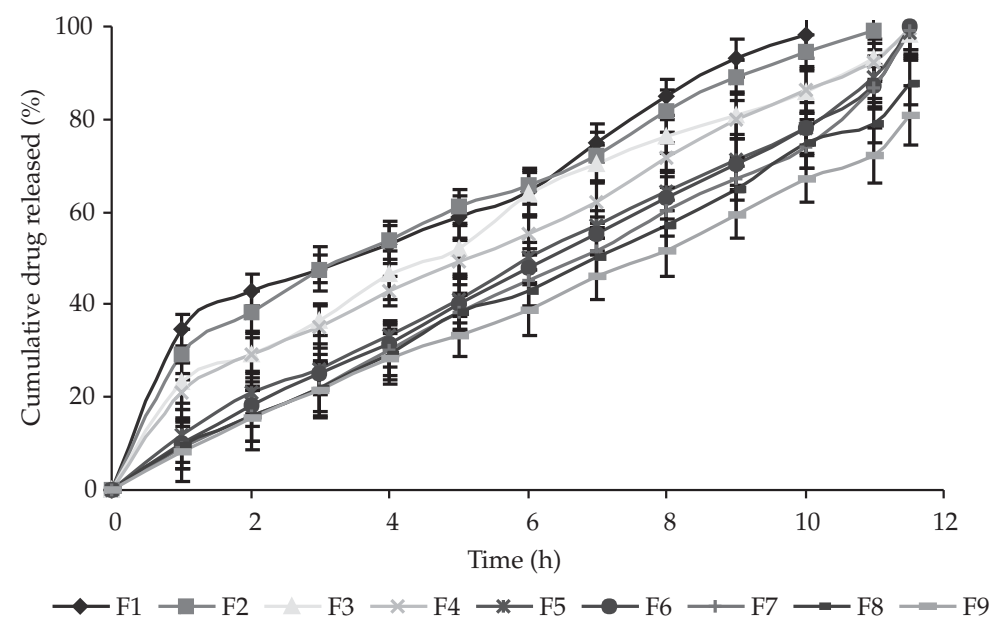

Fig. 2. In vitro drug release study of factorial design batches (mean $\pm \mathrm{SD}, n=3$ ). 
G. M. Patel and M. M. Patel: Compressed matrix dual-component vaginal drug delivery system containing metoclopramide hydrochloride, Acta Pharm. 59 (2009) 273-288.

Table V. Dependent variable from factorial design batches

\begin{tabular}{clcc}
\hline Batch code & $Q_{2}(\mathrm{~h})$ & $t_{50}(\mathrm{~h})$ & $t_{80}(\mathrm{~h})$ \\
\hline F1 & 43.07 & 3.90 & 7.51 \\
F2 & 38.54 & 4.11 & 7.91 \\
F3 & 29.2 & 4.96 & 8.91 \\
F4 & 29.17 & 5.25 & 9.16 \\
F5 & 20.78 & 6.05 & 9.86 \\
F6 & 18.42 & 6.19 & 9.94 \\
F7 & 16.18 & 6.47 & 10.27 \\
F8 & 16.01 & 6.86 & 11.03 \\
F9 & 15.57 & 7.56 & 12.18 \\
Checkpoint & 18.14 & 6.55 & 10.61 \\
\hline
\end{tabular}

pendent on the independent variables. The fitted equations (full - YF and reduced - YR) are shown in the following equations and in Table VI:

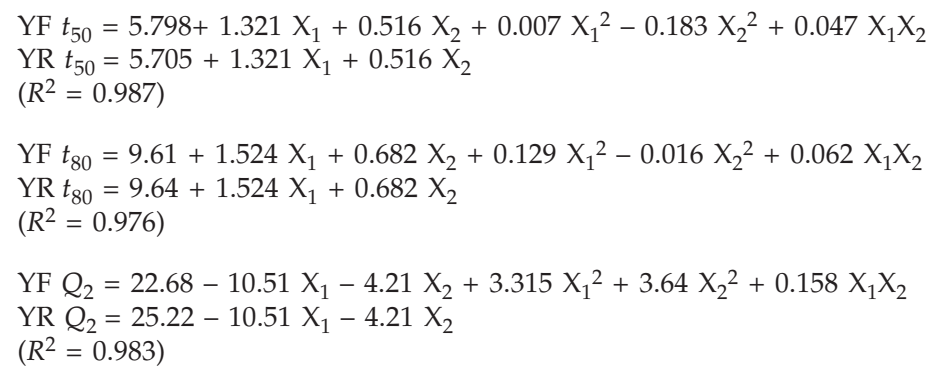

The polynomial equation can be used to draw conclusions after considering the magnitude of the coefficient and the mathematical sign it carries (i.e., positive or negative). Table VII shows the results of the analysis of variance (ANOVA), which was performed to identify insignificant factors. The high values of the coefficient of determination indicate a good fit i.e. good agreement between the dependent and independent variables.

The significance test for the regression coefficients was performed by applying the Student $F$-test. A coefficient is significant if the calculated $F$ is greater than the critical value of $F$. The results of multiple regression analysis showed that the ratio of HPMC K100M to Ucarflock 302 had a significant influence on $Q_{2}, t_{50}$ and $t_{80}(p<0.05$, Tables VI and VII).

The significance levels of coefficients $b_{12}, b_{11}$ and $b_{22}$ were found to be $0.0543,0.0973$ and 0.923 , respectively; hence they were omitted from the full model to generate the reduced model. The other coefficients were found to be significant at $p<0.05$; hence they were retained in the reduced model. The reduced model was tested partially to determine whether coefficients $b_{12}, b_{11}$ and $b_{22}$ contributed significant information to the prediction of $Q_{2}, t_{50}$ and $t_{80}$. The results of partial model testing are shown in Table VII. The 
G. M. Patel and M. M. Patel: Compressed matrix dual-component vaginal drug delivery system containing metoclopramide hydrochloride, Acta Pharm. 59 (2009) 273-288.

Table VI. Summary of the results of regression analysis

\begin{tabular}{|c|c|c|c|c|c|c|c|}
\hline \multirow[t]{2}{*}{ Model } & \multicolumn{7}{|c|}{ Coefficients for $Q 2$} \\
\hline & $\mathrm{b}_{0}$ & $b_{1}$ & $\mathrm{~b}_{2}$ & $\mathrm{~b}_{12}$ & $b_{11}$ & $\mathrm{~b}_{22}$ & $R^{2}$ \\
\hline FM & 22.68 & -10.51 & -4.21 & 3.315 & 3.64 & 0.158 & 0.983 \\
\hline \multirow[t]{3}{*}{$\mathrm{RM}$} & 25.22 & -10.51 & -4.21 & & & & 0.900 \\
\hline & \multicolumn{7}{|c|}{ Coefficients for $t_{50}$} \\
\hline & $\mathrm{b}_{0}$ & $b_{1}$ & $b_{2}$ & $\mathrm{~b}_{12}$ & $b_{11}$ & $\mathrm{~b}_{22}$ & $R^{2}$ \\
\hline FM & 5.798 & 1.321 & 0.516 & 0.007 & -0.183 & 0.047 & 0.987 \\
\hline \multirow[t]{3}{*}{ RM } & 5.705 & 1.321 & 0.516 & & & & 0.981 \\
\hline & \multicolumn{7}{|c|}{ Coefficients for $t_{80}$} \\
\hline & $\mathrm{b}_{0}$ & $b_{1}$ & $\mathrm{~b}_{2}$ & $\mathrm{~b}_{12}$ & $\mathrm{~b}_{11}$ & $\mathrm{~b}_{22}$ & $R^{2}$ \\
\hline FM & 9.61 & 1.524 & 0.682 & 0.129 & -0.016 & 0.062 & 0.976 \\
\hline RM & 9.64 & 1.524 & 0.682 & & & & 0.972 \\
\hline
\end{tabular}

FM - full model

$\mathrm{RM}$ - reduced model

Table VII. Calculation for partial testing of the model (ANOVA)

\begin{tabular}{|c|c|c|c|c|c|c|}
\hline For $Q 2$ & & & & & & \\
\hline Regression & DF & SS & MS & F & $\mathrm{R} 2$ & \\
\hline FM & 5 & 839.125 & 167.825 & 36.0014 & 0.9836 & $F_{\mathrm{cal}}=5.039$ \\
\hline RM & 2 & 768.643 & 384.321 & 27.2998 & 0.9009 & $F_{\mathrm{tab}}=9.28$ \\
\hline Error & & & & & & $D F=(3,3)$ \\
\hline FM & 3 & 13.9849 & 4.66163 & - & - & \\
\hline RM & 6 & 84.4669 & 14.0778 & - & - & \\
\hline \multicolumn{7}{|l|}{ For $t_{50}$} \\
\hline Regression & DF & SS & MS & $\mathrm{F}$ & $\mathrm{R} 2$ & \\
\hline FM & 5 & 12.1329 & 2.42657 & 45.6724 & 0.987 & $F_{\mathrm{cal}}=0.453$ \\
\hline $\mathrm{RM}$ & 2 & 12.0607 & 6.03035 & 156.263 & 0.9812 & $F_{\text {tab }}=9.28$ \\
\hline Error & & & & & & $D F=(3,3)$ \\
\hline FM & 3 & 0.15939 & 0.05313 & - & - & \\
\hline $\mathrm{RM}$ & 6 & 0.23155 & 0.03859 & - & - & \\
\hline \multicolumn{7}{|l|}{ For $t_{80}$} \\
\hline Regression & $\mathrm{DF}$ & SS & MS & F & R2 & \\
\hline FM & 5 & 16.795 & 3.359 & 25.4815 & 0.977 & $F_{\mathrm{cal}}=0.188$ \\
\hline RM & 2 & 16.7208 & 8.36039 & 106.804 & 0.9727 & $F_{\mathrm{tab}}=9.28$ \\
\hline Error & & & & & & $D F=(3,3)$ \\
\hline FM & 3 & 0.39546 & 0.13182 & - & - & \\
\hline RM & 6 & 0.46967 & 0.07828 & - & - & \\
\hline
\end{tabular}


G. M. Patel and M. M. Patel: Compressed matrix dual-component vaginal drug delivery system containing metoclopramide hydrochloride, Acta Pharm. 59 (2009) 273-288.
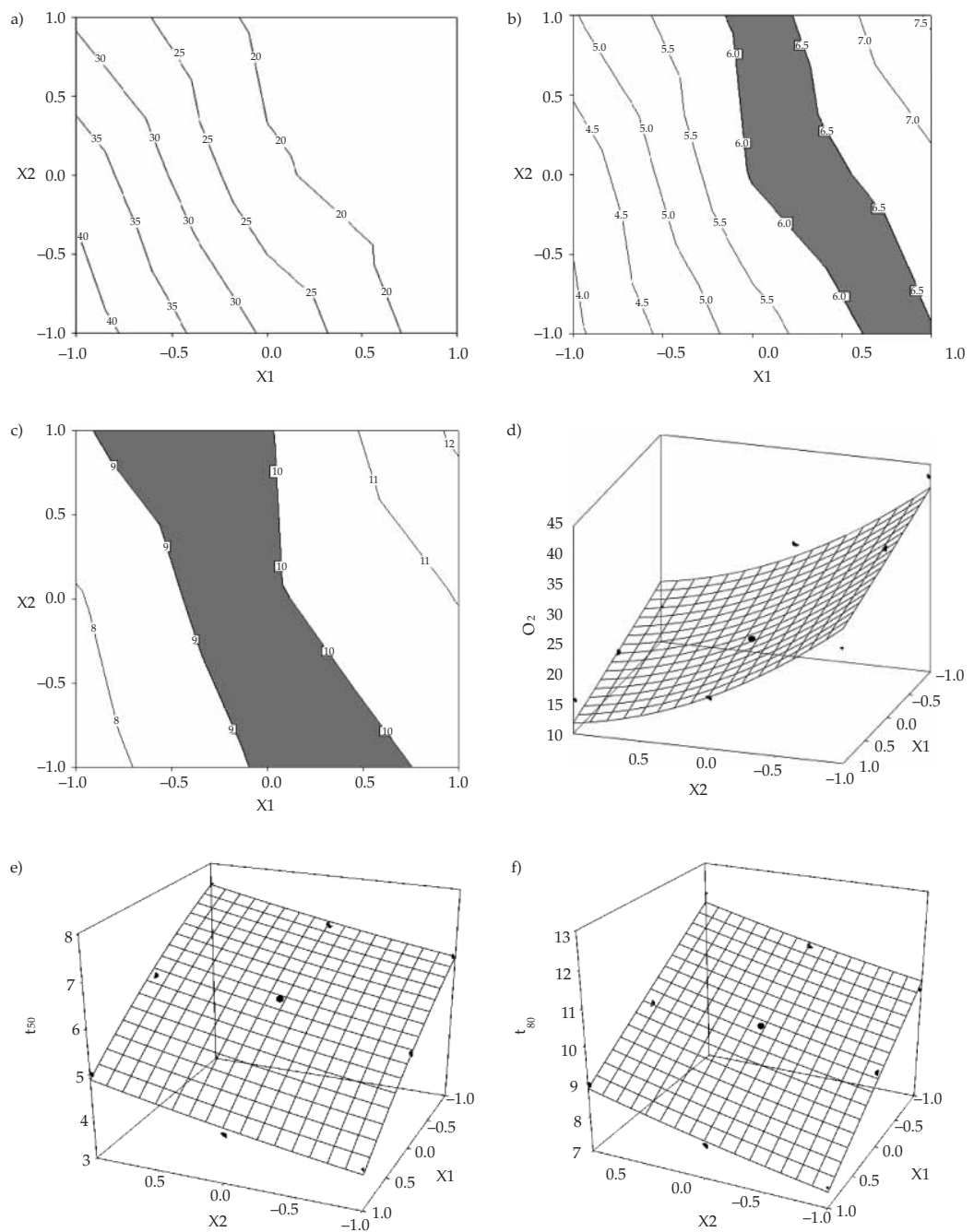

Fig. 3. Contour plots for: a) $Q_{2}$, b) $t_{50}$, c) $t_{80}$, and $3 \mathrm{D}$ mesh plot for: d) $Q_{2}$, e) $t_{50}$, f) $t_{80}$.

critical value of $F$ for $\infty=0.05$ is equal to $9.28(d f=3,3)$. Since the calculated value for $Q_{2}$ $(F=5.039)$ is less than the critical value, it may be concluded that the interaction term $b_{12}$ and polynomial terms $b_{11}$ and $b_{22}$ do not contribute significantly to the prediction of $Q_{2}$.

The critical value of $F$ for $\infty=0.05$ is equal to $9.28(\mathrm{df}=3,3)$. Since the calculated value for $t_{50}(F=0.453)$ is less then the critical value, it may be concluded that the interaction term $b_{12}$ and polynomial terms $b_{11}$ and $b_{22}$ do not contribute significantly to the prediction of $t_{50}$. The critical value of $F$ for $\infty=0.05$ is equal to $9.28(\mathrm{df}=3,3)$. Since the calculated value for $t_{80}(F=0.188)$ is less then the critical value, it may be concluded that 
G. M. Patel and M. M. Patel: Compressed matrix dual-component vaginal drug delivery system containing metoclopramide hydrochloride, Acta Pharm. 59 (2009) 273-288.

the interaction term $b_{12}$ and polynomial terms $b_{11}$ and $b_{22}$ do not contribute significantly to the prediction of $t_{50}$ and $t_{80}$, respectively.

An equation containing only statistically significant terms is then used for drawing contour plots to visualize the impact of changing variables. The optimum point may be identified from the plot and replicate trials may be run to verify prediction of the optimum response. Figs. 3a-f show the contour plots and 3D mesh plots of the amounts of HPMC K100M $\left(X_{1}\right)$ and of Ucarflock $302\left(X_{2}\right)$ versus $Q_{2}, t_{50}$ and $t_{80}$, respectively. The plot was drawn using the Sigma Plot software Version 11 (Systat Software, USA).

The data demonstrate that both $\mathrm{X}_{1}$ and $\mathrm{X}_{2}$ affect the drug release $\left(t_{50}\right.$ and $\left.t_{80}\right)$. It may also be concluded that the low level of $X_{1}$ (amount of HPMC K100M) and the higher level of $\mathrm{X}_{2}$ (amount of Ucarflock 302) favour the preparation of dual component vaginal tablets and that the drug release pattern may be changed by appropriate selection of $X_{1}$ and $X_{2}$ levels. Shaded areas in Figs. $3 b$ and $3 c( \pm 5 \%$ level from theoretical value) demonstrate the optimized area of individual dependent variables $\left(t_{50}\right.$ and $\left.t_{80}\right)$.

It was arbitrarily decided to select a batch of tablets that release 18-20\% drug within $2 \mathrm{~h}$. Batches F6 and F7 fall within acceptable criteria. A check point bach was prepared at $X_{1}=-0.2$ and $X_{2}=0.8$. It was expected from the reduced model that $t_{50}, t_{80}$ and $Q_{2}$ values of the check point batch should be $6.65 \mathrm{~h}, 10.72 \mathrm{~h}$ and $17.7 \%$, respectively. Table $\mathrm{V}$ shows that the results are as expected. Thus, we can conclude that the statistical model was mathematically valid.

The results in Table VIII indicate that batches F5, F6 and F7 fulfill the criteria reported by Moore and Flanner (20). However, batch F6 showed the highest $f 2$ (82.6) among all the batches, and this similarity was also reflected in the $t_{50}$ value.

Table VIII. Selection of optimized batch on the basis of similarity factor

\begin{tabular}{ccccc}
\hline \multirow{2}{*}{ Time $(\mathrm{h})$} & \multicolumn{3}{c}{ Batch code } \\
\cline { 2 - 5 } & $\begin{array}{c}\text { Theoretical } \\
\text { release profile }\end{array}$ & F5 & F6 & F7 \\
\hline 0 & 0 & 0 & 0 & 0 \\
1 & 4.65 & 11.67 & 10.01 & 9.14 \\
2 & 9.3 & 20.78 & 18.42 & 16.18 \\
3 & 18.66 & 26.09 & 25.11 & 22.04 \\
4 & 28 & 33.19 & 31.48 & 30.1 \\
5 & 37.3 & 41.08 & 40.17 & 38.24 \\
6 & 46.6 & 50.45 & 48.12 & 45.12 \\
7 & 56 & 57.24 & 55.19 & 51.38 \\
8 & 65.3 & 64.57 & 63.11 & 60.11 \\
9 & 74.6 & 71.19 & 70.14 & 67.12 \\
10 & 83.7 & 78.01 & 78.12 & 74.18 \\
11 & 93.3 & 89.05 & 87.1 & 86.78 \\
11.5 & 102.6 & 98.56 & 99.79 & 99.01 \\
$f_{2}$ & & 59.28 & 82.68 & 60.55 \\
\hline
\end{tabular}


G. M. Patel and M. M. Patel: Compressed matrix dual-component vaginal drug delivery system containing metoclopramide hydrochloride, Acta Pharm. 59 (2009) 273-288.

Fig. 4. Comparison of the theoretical release profile and dual component system.

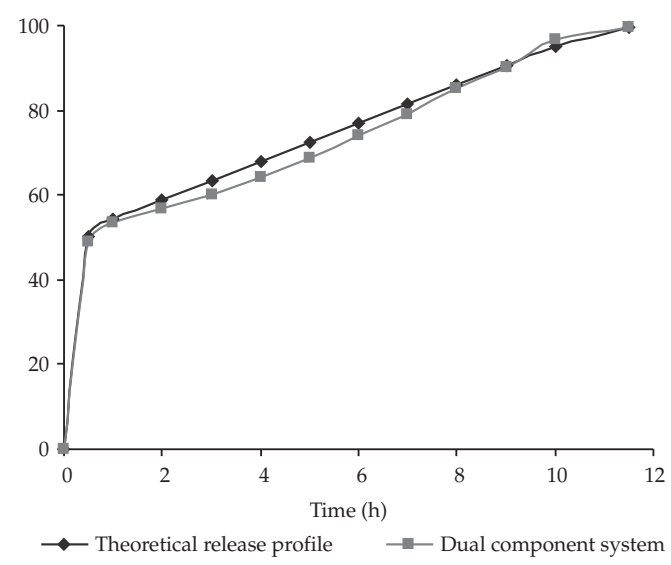

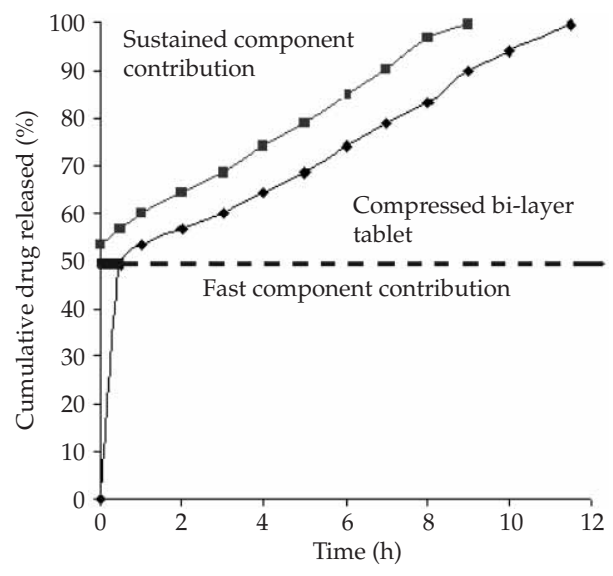

Fig. 5. Contributions of each component to release from the dual component system.

Fig. 4 compares the theoretical release profile and dual component system. Dualcomponent formulation has shown the ability to maintain a dissolution profile similar to that of the theoretical release profile, emphasizing their integrity $(f 2=82.6)$. For the calculation of $f 2$ of the sustained release component, the contribution of metoclopramide hydrochloride in the immediate release component of the compressed tablet system was subtracted from the total amount of drug released.

Fig. 5 shows the contributions of each component (fast/prolonged) to the release profile of metoclopramide hydrochloride from the compressed dual component system containing a polymer layer as a prolonged release component. According to the figure, the release profile is characterized by burst release within a few minutes (30 $\mathrm{min})$ followed by a slow release period, typical of a biphasic quick/slow delivery system. For both layers, upon contact with the dissolution media, there was rapid disintegration of the fast-releasing phase and the sustained release layer released the drug in a predictable manner. Prompt tablet disintegration was due to the presence of Ac-di-sol, which 
G. M. Patel and M. M. Patel: Compressed matrix dual-component vaginal drug delivery system containing metoclopramide hydrochloride, Acta Pharm. 59 (2009) 273-288.

Table IX. Short-term stability data of the mucoadhesive dual component tablet

\begin{tabular}{lcccc}
\hline & \multicolumn{4}{c}{ Duration of storage (month) } \\
\hline Characteristics & 0 & 1 & 3 & 6 \\
Resistance to crushing $\left(\mathrm{kg} \mathrm{cm}^{-2}\right)$ & $5.5 \pm 0.1$ & $5.5 \pm 0.1$ & $5.4 \pm 0.1$ & $5.4 \pm 0.1$ \\
Drug content (\%) & 99.57 & 99.12 & 99.13 & 98.99 \\
Ex vivo residence time (h) & 12.5 & 12.5 & 12.5 & 12.2 \\
Drug released (\%) & 99.5 & 99.5 & 99.1 & 98.9 \\
$t_{50}(\mathrm{~h})$ & 5.73 & 5.70 & 5.70 & 5.71 \\
Release kinetics $(n)$ & 1.008 & 1.001 & 1.000 & 1.000 \\
\hline
\end{tabular}

swells very quickly when in contact with water. After the initial phase, the release was dependent on the composition of the sustained release matrix tablet, particularly, the type and concentration of the polymers. The sustained release tablet kept the metoclopramide release slow for more than 11 hours.

The drug release data was fitted to the Korsmeyer-Peppas model. From the plot log $\left(M_{t} / M_{\infty}\right)$ vs. $\log t, n$ values were close to 1 ( $n=1.008, k=0.915$ units), indicating zero-order release kinetics $\left(R^{2}=0.998\right)$.

The ability of the HPMC K100M and Ucarflock 302 particles to hydrate and form a gel layer around a core is well known and is essential for sustaining and controlling the release of a drug from the matrix. Throughout the dissolution test, a continuous gel layer formed on the surface of the matrix due to hydrophilic polymers HPMC K100M and Ucarflock 302. After 12 hours of dissolution testing, it was evident that the gel layer around the HPMC K100M and Ucarflock 302 cores had retained its integrity, exhibiting a porous structure when observed under an optical microscope.

The results obtained from the ex vivo residence time revealed that higher polymer swelling at the interface enabled better interpenetration and entanglement and consequently stronger mucoadhesion. The residence time (the time required for complete tablet detachment) of the optimized formulation was $12.2 \mathrm{~h}$. From this result, it was predicted that the optimized formulation had the desired residency ex vivo.

The effect of aging was studied for the optimized formulation containing $30 \mathrm{mg}$ of the drug. The data shown in Table IX reveal no marked change in resistance to crushing, drug content and in vitro drug release $\left(5.4 \mathrm{~kg} \mathrm{~cm}^{-2}, 99.0 \%\right.$ and $98.1 \%$ after 6 months) respectively. A reduction in residence time was noticed approximately $10 \mathrm{~min}$ for stored formulation compared to the fresh one. The constant $n$ value (1.008 to 1.000 after 6 months) reveals that the release from the dual component mucoadhesive system is not affected by storage.

\section{CONCLUSIONS}

A dual-component vaginal quick/slow delivery system was achieved, characterized by an initial rapid release phase corresponding to the drug present in the immediate release layer, followed by a period of slow release, corresponding to the drug from the 
G. M. Patel and M. M. Patel: Compressed matrix dual-component vaginal drug delivery system containing metoclopramide hydrochloride, Acta Pharm. 59 (2009) 273-288.

sustained release layer. The design of the two different release phases can be easily adjusted in both the delivery rate and the ratio of dose fractions to the pharmacokinetics and therapeutic needs, to provide the desired in vitro profile. The results obtained with the dissolution test show that the release profile is dependent on both the type and amount of polymer in the sustained release layer. After immediate release of metoclopramide hydrochloride, both types of polymers (HPMC K100M and Ucarflock 302) were able to modulate the metoclopramide hydrochloride release for a prolonged time (almost 11 to $12 \mathrm{~h}$ ) with a dissolution profile similar to that of the theoretical release profile. Based on the $f 2$ value, this suggests their integrity after compaction, indicating the promising potential of the metoclopramide hydrochloride biphasic vaginal tablet as an alternative to the conventional dosage form.

\section{REFERENCES}

1. K. Vermani and S. Garg, The scope and potential of vaginal drug delivery, PSTT, 3 (2000) 359364; DOI: S1461-5347(00)00296-0.

2. P. Colombo, U. Conte and A. Gazzaniga, Drug release modulation by physical restrictions of matrix swelling, Int. J. Pharm. 63 (1990) 43-48; DOI: 10.1016/0378-5173(90)90099-P.

3. Y. Qiu, N. Chidambaram and K. Flood, Design and evaluation of layered diffusional matrices for zero-order sustained release, J. Control. Rel. 51 (1998) 123-130; DOI: PII S0168-3659(97)00119-3.

4. N. Chidambaram, W. Porter, K. Flood and Y. Qui, Formulation and characterization of new layered diffusional matrices for zero-order sustained release, J. Control. Rel. 52 (1998) 149-158; DOI: 10.1016/S0168-3659(97)00207-1.

5. U. Conte and L. Maggi, A flexible technology for the linear, pulsative and delayed release drugs, allowing for easy accommodation of difficult in vitro targets, J. Control. Rel. 64 (2000) 263-268; DOI: 10.1016/S0168-3659(99)00147-9.

6. N. M. Zakia, G. A. Awada, N. D. Mortadaa, S. Seham and A. E. Hady, Enhanced bioavailability of metoclopramide $\mathrm{HCl}$ by intranasal administration of a mucoadhesive in situ gel with modulated rheological and mucociliary transport properties, Eur. J. Pharm. Sci. 3 (2007) 296-307; DOI: 10.1016/j.ejps.2007.08.006.

7. S. Lybak, E. Kjellen, P. Nilsson, A. Tomaszewicz, J. Wennerberg and R. W. Pero, Normal tissue reactions in mice after combined treatment with metoclopramide and ionizing radiation, Acta Oncol. 31 (1992) 469-474.

8. J. Wennerberg, E. Kjellen, S. Lybak, R. Rydell and R. Pero, Biochemical modulation of chemotherapy and radiotherapy in head and neck cancer, Anticancer Res. 13 (1993) 2501-2506.

9. A. Olsson, Y. Sheng, E. Kjellen and R. W. Pero, In vivo tumor measurement of DNA damage, DNA repair and NAD pools as indicators of radiosensitization by metoclopramide, Carcinogenesis 16 (1995) 1029-1035.

10. R. A. Harrington, C. W. Hamilton, R. N. Brogden, J. A. Linkewich, J. A. Romankiewicz and R. C. Heel, Metoclopramide: an updated review of its pharmacological properties and clinical use, Drugs 25 (1983) 451-494.

11. D. M. Brahmankar and S. B. Jaiswal, Application of Pharmacokinetic Principles - Biopharmaceutics and Pharmacokinetics, $1^{\text {st }}$ ed., Vallaph Prakashan, Delhi 1998, p. 311.

12. H. C. Ansel, L. V. Allen and N. G. Popovich, Capsules and Tablets, in Pharmaceutical Dosage Forms and Drug Delivery Systems, 7th ed., Lippincott Williams \& Wilkins, Philadelphia 2002, pp. 204-209.

13. C. N. Patra, A. B. Kumar, H. K. Pandit, S. P. Singh and M. V. Devi, Design and evaluation of sustained release bilayer tablets of propranolol hydrochloride, Acta Pharm. 57 (2007) 479-489; DOI: 10.2478/v10007-007-0038-0. 
G. M. Patel and M. M. Patel: Compressed matrix dual-component vaginal drug delivery system containing metoclopramide hydrochloride, Acta Pharm. 59 (2009) 273-288.

14. United States Pharmacopoeia 28, National Formulary 23, Asian Edition, USP Convention, Rockville (MD) 2005, p. 1277.

15. Guidance for Industry, SUPAC-MR: Modified Release Solid Oral Dosage Forms. Scale-Up and Postapproval Changes: Chemistry, Manufacturing, and Controls; In Vitro Dissolution Testing and In Vivo Bioequivalence Documentation, U. S. Department of Health and Human Services, Food and Drug Administration, Center for Drug Evaluation and Research (CDER) September 1997, CMC 8, Rockville (MD) 1997, p. 32.

16. P. Costa, J. Manuel and S. Labao, Modeling and comparison of dissolution profiles, Eur. J. Pharm. Sci. 13 (2001) 123-133; DOI: 10.1016/S0928-0987(01)00095-1.

17. R. W. Korsmeyer, R. Gurny, E. Docler, P. Buri and N. A. Peppas, Mechanism of solute release from porous hydrophilic polymers, Int. J. Pharm. 15 (1983) 25-35; DOI: 10.1016/0378-5173(83) 90064-9.

18. N. A. Peppas, Analysis of Fickian and non Fickian drug release from polymers, Pharm. Acta Helv. 60 (1985) 110-111.

19. N. Adel, N. Fatma, A. Ismail, N. A. Boraie and L. M. Mortada, Mucoadhesive delivery systems. I. Evaluation of mucoadhesive polymers for buccal tablet formulation, Drug. Dev. Ind. Pharm. 30 (2004) 985-993; DOI: 10.1081/DDC-200037245.

20. J. Moore and H. Flanner, Mathematical comparison of dissolution profiles, Pharm. Tech. 20 (1996) 64-74.

\section{$S A \check{Z} E T A K$}

\section{Komprimirani matriksni dvokomponentni sustavi s metoklopramid hidrokloridom}

GEETA M. PATEL i MADHABHAI M. PATEL

Cilj rada bila je priprava brzog/sporog bifazičnog sustava za isporuku metoklopramid hidroklorida koristeći dezintegrator Ac-di-sol za sloj koji brzo oslobađa i hidroksipropil metilcelulozu K100M i Ucarflock 302 za moduliranje oslobađanja ljekovite tvari. Dvokomponentna tableta sa slojem za usporeno i slojem za brzo oslobađanje pripravljena je metodom izravne kompresije. $3^{2}$ faktorijalni dizajn primijenjen je za sistematsko optimiranje profila oslobađanja ljekovite tvari u sloju za usporeno oslobađanje. Rezultati ukazuju na to da su mala količina HPMC K100M i velika količina Ucarflock 302 bitne za usporeno oslobađanje metoklopramid hidroklorida $\mathrm{u}$ dvokomponentnom sustavu za vaginalnu upotrebu. Ex vivo ispitivanja pokazuju da se pripravak zadržava više od 10 h. Naglo oslobađanje lijeka omogućava brzo postizanje udarne doze, a postupno oslobađanje tijekom $12 \mathrm{~h}$ održavanje učinkovite koncentracije, čime se rješava problem opetovane primjene, posebno u trudnoći.

Ključne riječi: dvokomponentni sustav, mukoadhezija, faktorijalni dizajn, brzo/sporo oslobađanje, vaginalna primjena

Department of Pharmaceutics and Pharmaceutical Technology, S. K. Patel College of Pharmaceutical Education and Research, Ganpat University, Kherva-382711, Gujarat, India

Kalol Institute of Pharmacy, Kalol, Gujarat, India 